\title{
Vitamin D in respiratory diseases
}

\author{
A Goolam Mahomed, MB BCh, FCP(SA), FCCP \\ Department of Intensive Care, Sefako Makgatho Health Sciences University, Pretoria, South Africa \\ Corresponding author: A Goolam Mahomed (akhtergm@telkomsa.net)
}

Vitamin D has traditionally been known for its role in bone homeostasis with its effects on calcium and phosphate absorption and secretion. However, new evidence is emerging of its effects on a number of other cells, especially the immune system. This article reviews the role of vitamin $\mathrm{D}$ as it pertains to the respiratory tract and respiratory diseases.

S Afr Respir J 2017;23(1):14-18. DOI:10.7196/SARJ.2017.v23i1.156

\begin{abstract}
Vitamin D belongs to a group of fat-soluble secosteroids and is required for intestinal absorption of calcium $\left(\mathrm{Ca}^{2+}\right)$ and phosphate $\left(\mathrm{PO}_{4}{ }^{3-}\right)$. In humans, vitamin $\mathrm{D}$ is present as ergocalciferol (vitamin $\mathrm{D}_{2}$ ) or cholecalciferol (vitamin $\mathrm{D}_{3}$ ), and both forms can be ingested from the diet and/or supplements. The body can also synthesise vitamin $\mathrm{D}$ from cholesterol when sun exposure is adequate, hence it has been nicknamed the 'sunshine vitamin..${ }^{[1]}$ Recently, interest has grown in the role of vitamin D in many non-skeletal medical conditions, including respiratory infection and lung function. ${ }^{[2]}$ Emerging evidence indicates that vitamin D-mediated innate immunity is important in host defences against respiratory tract pathogens. ${ }^{[3]}$ Observational studies suggest that vitamin D deficiency increases the risk of respiratory infections, incident wheezing illness in children and adults, and can cause asthma exacerbations. Vitamin $\mathrm{D}$ also modulates regulatory T-cell function and interleukin-10 (IL-10) production, which may increase the therapeutic response to glucocorticoids in steroid-resistant asthma.
\end{abstract}

\section{History}

In 1914, American researchers McCollum and Davis discovered a substance in cod liver oil which was later called 'vitamin A'. In 1922, McCollum tested modified cod liver oil in which the vitamin A had been denatured. The modified oil cured rickets in sick dogs, so McCollum concluded the factor in cod liver oil that cured rickets was distinct from vitamin A. He called it vitamin D because it was the fourth vitamin to be named. ${ }^{[4]}$ In 1923, American biochemist Harry Steenbock demonstrated that the irradiation of foodstuffs, especially milk, led to a cure for rickets. In 1932, an academic collaboration between Bourdillon, Rosenheim, King and Callow led to the isolation and characterisation of vitamin D and later in the 1930s, Windaus further clarified the chemical structure of vitamin D. By 1972, Holick had discovered that vitamin D was metabolised to two active forms, i.e. calcidiol and calcitriol. ${ }^{[5,6]}$

\section{Recommended dietary allowance of vitamin D}

The US Institute of Medicine (IOM) recommended dietary allowance of vitamin D is 400 international units (IU) per day for children younger than 1 year of age, $600 \mathrm{IU}$ per day for children at least 1 year of age and adults up to 70 years, and $800 \mathrm{IU}$ per day for older adults.
The US IOM concluded that serum 25-hydroxyvitamin D $(25(\mathrm{OH}) \mathrm{D})$ of $20 \mathrm{ng} / \mathrm{mL}$ or more would cover the requirements of $97.5 \%$ of the population. ${ }^{[7]}$ The US Endocrine Society's Clinical Practice Guidelines suggest that $400-1000 \mathrm{IU} /$ day may be needed for children aged $<1$ year, $600-1000 \mathrm{IU} /$ day for children aged $\geq 1$ year, and 1500 $2000 \mathrm{IU} /$ day for adults aged $\geq 19$ years to maintain $25(\mathrm{OH}) \mathrm{D}$ above the optimal level of $30 \mathrm{ng} / \mathrm{mL}^{[8]}$

\section{Sources of vitamin D}

Sources of vitamin D include sun exposure, diet and supplements. Vitamin $\mathrm{D}_{2}$ is obtained from ultraviolet irradiation of the yeast sterol, ergosterol, and remains the only pharmaceutical form of vitamin $\mathrm{D}$ approved by the US Food and Drug Administration. Vitamin $\mathrm{D}_{3}$ is synthesised in the skin and is present in oil-rich fish such as salmon, mackerel and herring. Both vitamin $\mathrm{D}_{2}$ and vitamin $\mathrm{D}_{3}$ are used in food fortification and supplements. The major foods fortified with vitamin $\mathrm{D}\left(\mathrm{D}_{2}\right.$ or $\left.\mathrm{D}_{3}\right)$ are milk, yoghurts, cheeses, orange juice and cereals. Vitamin D is metabolised in the liver to 25-hydroxyvitamin $\mathrm{D}_{3}\left(25(\mathrm{OH}) \mathrm{D}_{3}\right)$, which is the best available indicator of vitamin $\mathrm{D}$ status. In the kidneys, $25(\mathrm{OH}) \mathrm{D}_{3}$ is metabolised to its active form, 1,25-dihydroxyvitamin $\mathrm{D}_{3},\left(1,25(\mathrm{OH})_{2} \mathrm{D}_{3}\right)$. The levels of $1,25(\mathrm{OH})_{2} \mathrm{D}_{3}$ do not reflect vitamin $\mathrm{D}$ status as they are regulated by parathyroid hormone, $\mathrm{Ca}^{2+}$ and $\mathrm{PO}_{4}{ }^{3-}$ levels, and fibroblast growth factor 23. ${ }^{[7,8]}$

\section{Physiology of vitamin D}

Intestinal $\mathrm{Ca}^{2+}$ and $\mathrm{PO}_{4}{ }^{3-}$ absorption is regulated by $1,25(\mathrm{OH})_{2} \mathrm{D}_{3}$, and with severe vitamin $\mathrm{D}$ deficiency the efficiency of $\mathrm{Ca}^{2+}$ absorption decreases from 30 - 40 to 10 - 15\%. Vitamin D deficiency also stimulates the parathyroid glands, leading to secondary hyperparathyroidism. Secondary hyperparathyroidism maintains serum $\mathrm{Ca}^{2+}$ in the normal range at the expense of mobilising $\mathrm{Ca}^{2+}$ from the bone, and increases urinary $\mathrm{PO}_{4}^{3-}$ loss, resulting in a decrease in serum $\mathrm{PO}_{4}^{3-}$ level and an inadequate calcium-phosphate product $\left(\mathrm{Ca}^{2+} \times \mathrm{PO}_{4}^{3-}\right)$. This results in a defect in bone mineralisation, which leads to rickets in children and osteomalacia in adults. ${ }^{[7,8]}$

\section{Non-skeletal actions of vitamin D}

The lung, brain, prostate, breast and colon tissues, among others, as well as immune system cells, express the vitamin D receptor (VDR) and responds to $1,25(\mathrm{OH})_{2} \mathrm{D}_{3}$, the active form of vitamin $\mathrm{D}$, which 
is the ligand for the VDR receptor. In fact, cells without the VDR receptor are rare. In addition, some of these tissues and cells express the enzyme 25-hydroxyvitamin D-1 $\alpha$-hydroxylase, which is encoded by the CYP27B1 gene. Binding of $1,25(\mathrm{OH})_{2} \mathrm{D}_{3}$ to the VDR leads to the formation of a heterodimer with retinoid $\mathrm{X}$ receptor, which combines with vitamin $\mathrm{D}$ response elements (VDREs) that then regulate gene expression. ${ }^{[9]}$ Directly or indirectly, $1,25(\mathrm{OH})_{2} \mathrm{D}_{3}$ controls $>200$ genes, including genes responsible for the regulation of cellular proliferation, differentiation, apoptosis and angiogenesis. It decreases cellular proliferation of both normal and malignant cells, and induces their terminal differentiation. ${ }^{[3]}$ One practical application is the use of $1,25(\mathrm{OH})_{2} \mathrm{D}_{3}$ and its active analogues for the treatment of psoriasis. ${ }^{[2]}$ $1,25(\mathrm{OH})_{2} \mathrm{D}_{3}$ is also a potent immunomodulator. Monocytes and macrophages exposed to a lipopolysaccharide or to Mycobacterium tuberculosis up-regulate the VDR gene and the 25-hydroxyvitamin $\mathrm{D}$-1a-hydroxylase gene. Increased production of $1,25(\mathrm{OH})_{2} \mathrm{D}_{3}$ results in synthesis of cathelicidin, a peptide capable of destroying M. tuberculosis as well as other infectious agents. When serum levels of $25(\mathrm{OH}) \mathrm{D}_{3}$ fall below $20 \mathrm{ng} / \mathrm{mL}(50 \mathrm{nmol} / \mathrm{L})$, the monocyte or macrophage is prevented from initiating this innate immune response. ${ }^{[3]} 1,25-(\mathrm{OH})_{2} \mathrm{D}_{3}$ also inhibits renin synthesis, increases insulin production and increases myocardial contractility. ${ }^{[2]}$

\section{Asthma and vitamin D levels}

The majority of studies report an inverse association between serum $25(\mathrm{OH}) \mathrm{D}_{3}$ levels and asthma morbidity. ${ }^{[9]}$ Vitamin D may play a causal role in asthma pathophysiology and vitamin D status may also impact on asthma therapy via a number of mechanisms, which include its antiviral properties, enhanced steroid responsiveness and down-regulation of atopy. It may also influence asthma by regulating the expression of disease-susceptibility genes. Biologically, there are data to suggest that $1,25(\mathrm{OH})_{2} \mathrm{D}_{3}$ can directly enhance secretion of the anti-inflammatory molecule IL-10 from regulatory T-cells derived from steroid-resistant individuals with asthma. ${ }^{[3]}$ In vitro, $1,25(\mathrm{OH})_{2} \mathrm{D}_{3}$ regulates inflammatory responses in airway epithelial cells and airway smooth muscle cells, both of which may be targets of corticosteroid therapy. ${ }^{[3]}$

The role of maternal vitamin D levels and their association with childhood wheeze and atopy is somewhat controversial. Hypponen et al. ${ }^{[10]}$ found that vitamin D supplementation increased the risk of asthma in Finnish infants, but many recent studies have come to different conclusions. Wills et al.$^{[11]}$ found no evidence that maternal levels of vitamin D correlate with childhood atopy or asthma, but the Vitamin D Antenatal Asthma Reduction Trial (VDAART) study found that vitamin D supplementation during pregnancy led to decreased levels of asthma and wheezing. ${ }^{[12]}$ In the Generation $\mathrm{R}$ Study, Gazibara et al.$^{[13]}$ found that maternal vitamin D levels did not correlate with asthma, but low levels of $25(\mathrm{OH}) \mathrm{D}_{3}$ at birth in infants were associated with higher airway resistance in childhood. In a recent meta-analysis of 15 prospective studies, Song et al. ${ }^{[14]}$ suggested there may be a U-shaped association between maternal $25(\mathrm{OH}) \mathrm{D}_{3}$ levels and asthma, with the lowest risk of asthma at approximately $70 \mathrm{nmol} / \mathrm{L}$ of $25(\mathrm{OH}) \mathrm{D}_{3}$.

In the HUNT study of a cohort of 25616 Norwegian adults, the authors showed that low vitamin D status was not significantly associated with incident asthma in most adults, but it may have increased risk in men without allergies. ${ }^{[15]}$ In contrast, Korn et al. ${ }^{[16]}$ found that vitamin D deficiency and insufficiency were clearly associated with asthma, and also with poor control of asthma. A number of recent trials using vitamin D replacement therapy did not show improvement in asthma control. The Vitamin D Addon Therapy Enhances Corticosteroid Responsiveness in Asthma (VIDA) trial studied adult patients with symptomatic asthma and a serum $25(\mathrm{OH}) \mathrm{D}_{3}$ level of $<30 \mathrm{ng} / \mathrm{mL}$ across nine academic medical centres in the USA. Oral vitamin $\mathrm{D}_{3}(100000 \mathrm{IU}$ once, then $4000 \mathrm{IU} /$ day for 28 weeks; $n=201)$ or placebo $(n=207)$ was added to inhaled ciclesonide $(320 \mu \mathrm{g} / \mathrm{d})$. Vitamin $\mathrm{D}_{3}$ did not reduce the rate of first treatment failure or exacerbation in adults with persistent asthma and vitamin D insufficiency. ${ }^{[17]}$ Similarly, a trial of bolus-dose vitamin $\mathrm{D}_{3}$ supplementation did not influence exacerbation time for asthma or upper respiratory tract infections (URTIs) in adults with vitamin D deficiency. ${ }^{[18]}$ A Cochrane meta-analysis recently showed that vitamin D supplementation does reduce the risk of severe exacerbations, and improves asthma symptom control in people with mild to moderate asthma. ${ }^{[19]}$

\section{Vitamin D and chronic obstructive pulmonary disease}

Low serum $25(\mathrm{OH}) \mathrm{D}_{3}$ levels have been associated with lower forced expiratory volume in 1 second (FEV1), impaired immunological control, and increased airway inflammation. ${ }^{[20,21]}$ Many patients with chronic obstructive pulmonary disease (COPD) have a vitamin D deficiency, and therefore the effects of vitamin D supplementation may extend beyond preventing osteoporosis. In a recent study to determine if baseline $25(\mathrm{OH}) \mathrm{D}_{3}$ levels relate to subsequent acute exacerbation of COPD (AECOPD) in a cohort of patients at high risk for AECOPD, plasma $25(\mathrm{OH}) \mathrm{D}_{3}$ was measured at baseline in 973 participants on entry into a 1-year study designed to determine if daily azithromycin decreased the incidence of AECOPD. Relationships between baseline $25(\mathrm{OH}) \mathrm{D}_{3}$ and AECOPD over 1 year were analysed with time to first AECOPD as the primary outcome and exacerbation rate as the secondary outcome. In this largely white (85\%) cohort of North American patients with severe COPD (mean FEV1 $1.12 \mathrm{~L} ; 40 \%$ of predicted), the mean (SD) $25(\mathrm{OH}) \mathrm{D}_{3}$ was $25.7(12.8) \mathrm{ng} / \mathrm{mL}$. A total of $33.1 \%$ of participants were vitamin $D$ insufficient $(\geq 20 \mathrm{ng} / \mathrm{mL}-<30 \mathrm{ng} / \mathrm{mL})$; $32 \%$ were vitamin D-deficient $(<20 \mathrm{ng} / \mathrm{mL})$, and $8.4 \%$ had severe vitamin $\mathrm{D}$ deficiency $(<10 \mathrm{ng} / \mathrm{mL})$. Baseline $25(\mathrm{OH}) \mathrm{D}_{3}$ levels had no relationship to time to first AECOPD or AECOPD rates, and the authors concluded that in patients with severe COPD, baseline $25(\mathrm{OH}) \mathrm{D}_{3}$ levels are not predictive of subsequent AECOPD. ${ }^{[22]}$ In another study following 97 COPD patients at the Royal Free Hospital (UK), low $25(\mathrm{OH}) \mathrm{D}_{3}$ levels were not associated with frequent exacerbations and did not increase susceptibility to human rhinovirus infection. ${ }^{[23]}$ In a randomised, single-centre, double-blind, placebo-controlled trial in Belgium, 182 patients with moderate to very severe COPD and a history of recent exacerbations were given 100000 IU of vitamin D supplementation or a placebo every 4 weeks for 1 year. The primary outcome was time to first exacerbation. Secondary outcomes were exacerbation rate, time to first hospitalisation, time to second exacerbation, FEV1, quality of life, and death. Mean serum $25(\mathrm{OH}) \mathrm{D}_{3}$ levels increased significantly in the vitamin D group compared 
with the placebo group. The median time to first exacerbation did not significantly differ between the groups, nor did exacerbation rates, FEV1, hospitalisation, quality of life, and death. However, a post hoc analysis in 30 participants with severe vitamin D deficiency (serum $25(\mathrm{OH}) \mathrm{D}_{3}$ levels $<10 \mathrm{ng} / \mathrm{mL}$ ) at baseline showed a significant reduction in exacerbations in the vitamin D-deficient group. ${ }^{[24]}$ ViDiCO (Vitamin D Supplementation in Patients with Chronic Obstructive Pulmonary Disease), another recent study on vitamin $\mathrm{D}_{3}$ supplementation in patients with COPD, found that supplementation protected against moderate or severe exacerbations, but not URTIs, in patients with baseline $25(\mathrm{OH}) \mathrm{D}_{3}$ levels of $>50 \mathrm{nmol} / \mathrm{L} .{ }^{[25]}$ Vitamin $\mathrm{D}$ supplementation has also been suggested for improving physical performance, but a recent randomised trial did not show any benefits in this regard. ${ }^{[26]}$ Although vitamin $\mathrm{D}$ deficiency may contribute to morbidity in COPD patients, a lack of vitamin D does not appear to contribute to excess mortality. ${ }^{[27]}$

\section{Tuberculosis and vitamin D}

The innate immune response is important in the defence against M. tuberculosis. Toll-like receptor triggering via vitamin $\mathrm{D}$ and cathelicidin is important in this response and may explain why black Americans, who are often vitamin D deficient, are more prone to contracting TB than are whites, and tend to have a more aggressive form of the disease. ${ }^{[28]}$ Vitamin D deficiency has been linked to a higher prevalence of TB, and this may in part be explained by genetic polymorphisms of the VDR and seasonal variation in vitamin $\mathrm{D}$ levels, which have also been linked to susceptibility to TB. ${ }^{[29-33]}$ The use of vitamin $\mathrm{D}$ as an adjunct to chemotherapy for TB has been tested in several clinical studies. Most of these studies have found beneficial effects, and a recent clinical trial in Pakistan, the SUCCINT (Supplementary Cholecalciferol in Recovery from Tuberculosis) study, showed accelerated clinical and radiographical improvement in those given supplemental high-dose vitamin $\mathrm{D} .{ }^{[34]}$ They also showed an improved immunological response, which was borne out by Coussens et al. ${ }^{[35]}$ in another study.

\section{Vitamin D, pneumonia and URTIs}

Vitamin $\mathrm{D}$ regulates the production of the antimicrobial peptides cathelicidin and $\beta$-defensin-2 ( $\beta \mathrm{D} 2)$, which play an important role in the innate immune response to infection. Therefore, vitamin $D$ mayhave a role in prevention and treatment of acute infections such as pneumonia. ${ }^{[36,37]}$ Vitamin D deficiency in children has been strongly associated with the risk of acute lower respiratory tract infections (LRTIs) in a number of settings. In Ethiopia, for example, researchers found that $42 \%$ of children hospitalised for pneumonia had rickets, or severe vitamin D deficiency. ${ }^{[38]}$ Associations between mortality and serum levels of $25(\mathrm{OH}) \mathrm{D}_{3}$, cathelicidin and $\beta \mathrm{D} 2$ were investigated in a prospective cohort of 112 patients admitted with community-acquired pneumonia during winter in New Zealand. Severe $25(\mathrm{OH}) \mathrm{D}_{3}$ deficiency $(<30 \mathrm{nmol} / \mathrm{L})$ was common in this population (15\%), and was associated with a higher 30 -day mortality rate compared with patients with sufficient $25(\mathrm{OH}) \mathrm{D}_{3}$. These associations were not explained by differences in age, comorbidities or the severity of the acute illness. Neither cathelicidin nor $\beta$ D2 levels predicted mortality, although there was a trend towards increased mortality with lower cathelicidin $(p=0.053)$.
Neither cathelicidin nor $\beta D 2$ levels correlated with $25(\mathrm{OH}) \mathrm{D}_{3}$. The authors concluded that $25(\mathrm{OH}) \mathrm{D}_{3}$ deficiency is associated with increased mortality in patients admitted to hospital with communityacquired pneumonia during winter. ${ }^{[39]}$ In a prospective cohort study of 272 hospitalised community acquired pneumonia patients, $25(\mathrm{OH}) \mathrm{D}_{3}$, leukocytes, C-reactive protein, total cortisol, the Pneumonia Severity Index score and CURB-65 score were measured on admission. Major outcome measures were intensive care unit (ICU) admission and 30-day mortality. A total of 143 (53\%) patients were vitamin D deficient $(<50 \mathrm{nmol} / \mathrm{L}), 79$ (29\%) patients were vitamin $\mathrm{D}$ insufficient $(50-75 \mathrm{nmol} / \mathrm{L})$, and $50(18 \%)$ patients were vitamin D sufficient $(>75 \mathrm{nmol} / \mathrm{L})$. Vitamin D deficiency was associated with an increased risk of ICU admission and 30-day mortality independent of other factors. ${ }^{[40]}$ There have been very few nutritional interventions aimed at the treatment or prevention of acute LRTIs published thus far. A randomised control trial in an area of high vitamin D deficiency in Afghanistan showed that one high dose of vitamin $\mathrm{D}_{3}$ combined with antibiotic treatment reduced the reoccurrence of pneumonia in children aged 1 - 36 months who had been hospitalised for pneumonia. ${ }^{[41]}$ However, there are conflicting results from another randomised, placebo-controlled trial by the same group in the same area. Oral vitamin $\mathrm{D}_{3}(100000 \mathrm{IU}, n=1524)$ was compared with a placebo $(n=1522)$ and given to children aged $1-11$ months in Kabul, Afghanistan. There was no significant difference between the incidence of first or only pneumonia between the vitamin $\mathrm{D}$ and the placebo group. The authors concluded that quarterly bolus doses of oral vitamin $\mathrm{D}_{3}$ supplementation to infants were not an effective intervention to reduce the incidence of pneumonia in infants in this setting. ${ }^{[42]}$ In a study published by Choudhary and Gupta, ${ }^{[43]}$ short-term supplementation with oral vitamin D (1 000 - 2000 IU per day for 5 days) had no beneficial effect on the resolution of severe pneumonia in under- 5 children.

Vitamin $\mathrm{D}$ also modulates the innate response to respiratory viral infections. ${ }^{[44]}$ Monthly high-dose vitamin $\mathrm{D}_{3}$ supplementation in elderly patients has been shown to reduce the incidence of acute respiratory tract infections. ${ }^{[45]}$ In immunosuppressed patients and those with frequent respiratory tract infections, vitamin D supplementation has been shown to be of benefit. ${ }^{[46]}$ In a recent meta-analysis of 25 randomised controlled trials, vitamin D supplementation was found to be a safe intervention, and it reduced the rate of acute respiratory tract infections, particularly in those who were initially vitamin $\mathrm{D}$ deficient. Those who were given daily or weekly doses benefited, but not those given bolus doses. ${ }^{[4]}$

\section{Vitamin D and cystic fibrosis}

Vitamin D deficiency is common in young children with cystic fibrosis, even in children with pancreatic sufficiency. ${ }^{[48]}$ Higher levels of $25(\mathrm{OH}) \mathrm{D}_{3}$ are associated with lower rates of pulmonary exacerbations and, in adolescents, with better lung functions, as reflected by a higher FEV1. ${ }^{[49]}$ Supplementation with vitamin D in patients with cystic fibrosis is a challenge because of poor absorption rates for vitamin $\mathrm{D}$ in these patients. In a recent pilot trial of vitamin D supplementation, higher doses of oral vitamin D were required to achieve adequate serum levels. The trial showed benefits of supplementation on quality of life, reduced inflammation and improved lung functions. ${ }^{[50]}$ 


\section{Conclusion}

Vitamin D deficiency is associated with a number of respiratory diseases, with notable effects on respiratory infections and lung function. Supplementation with vitamin D appears to improve many lung conditions. The evidence for vitamin D supplementation is not so clear-cut in obstructive airways disease such as COPD and asthma, but it is definitely beneficial in TB, and new evidence is mounting that it may be useful in patients with acute respiratory tract infections, particularly in individuals that are vitamin $\mathrm{D}$ deficient. Trials in patients with cystic fibrosis are at an early stage. The optimum route and dose for vitamin D supplementation still needs to be worked out, but recent analysis favours daily or weekly supplementation over bolus dosing. The genetic variability of the VDR may impact on outcomes. The development of new vitamin $\mathrm{D}$ analogues that target the inflammatory pathway without affecting calcium metabolism will be something for the future. ${ }^{[51]}$

1. Nair R, Maseeh A. Vitamin D: The 'sunshine' vitamin. J Pharmacol Pharmacother 2012;3(2):118-126. https://doi.org/10.4103/0976-500X.95506

2. Rosen CJ, Adams JS, Bikle DD, et al. The nonskeletal effects of vitamin D: An Endocrine Society scientific statement. Endocr Rev 2012;33(3):456-492. https://doi. org/10.1210/er.2012-1000

3. Hansdottir S, Monick MM. Vitamin D effects on lung immunity and respiratory diseases. Vitam Horm 2011;86:217-237. https://doi.org/10.1016/b978-0-12-3869609.00009-5

4. DeLuca HF. History of the discovery of Vitamin D and its active metabolites. Bonekey Rep 2014;479(3):1-8. https://doi.org/10.1038/bonekey.2013.213

5. Holick MF, Schnoes HK, DeLuca HF. Identification of 1,25-dihydroxycholecalciferol, a form of vitamin D3 metabolically active in the intestine. Proc Natl Acad Sci USA 1971;68(4):803-804 .

6. Holick MF, DeLuca HF, Avioli LV. Isolation and identification of 25-hydroxycholecalciferol from human plasma. Arch Intern Med 1972;129(1):56-61.

7. Holick MF. Vitamin D deficiency. N Engl J Med 2007;357(3):266-281. https://doi. org/10.1056/nejmra070553

8. Pramyothin P, Holick MF. Vitamin D supplementation. Guidelines and evidence for subclinical deficiency. Curr Opin Gastroenterol 2012;28(2):139-150. https://doi. org/10.1097/mog.0b013e32835004dc

9. Paul G, Brehm JM, Alcorn JF, et al. Vitamin D and asthma. Am J Respir Crit Care Med 2012;185(2):124-132. https://doi.org/10.1164/rccm.201108-1502ci

10. Hypponen E, Sovio U, Wjst M, et al. Infant vitamin D supplementation and allergic conditions in adulthood: Northern Finland birth cohort 1966. Ann N Y Acad Sci 2004;1037(1):84-95. https://doi.org/10.1196/annals.1337.013

11. Wills AK, Shaheen SO, Granell R, et al. Maternal 25-hydroxyvitamin D and its association with childhood atopic outcomes and lung function. Clin Exp Allergy 2013;43(10):1180-1188. https://doi.org/10.1111/cea.12172

12. Litonjua AA, Carey VJ, Laranjo N, et al. Effect of prenatal supplementation with vitamin $\mathrm{D}$ on asthma or recurrent wheezing in offspring by age 3 years: The VDAART randomized clinical trial. JAMA 2016;315(4):362-370. https://doi.org/10.1001/ jama.2015.18589

13. Gazibara T, den Dekker HT, de Jongste JC et al. Association of maternal and fetal 25-hydroxyvitamin D levels with childhood lung function and asthma: The Generation R study. Clin Exp Allergy 2016;46(2):337-346. https://doi.org/10.1111/ cea. 12645

14. Song H, Yang L, Jia C. Maternal vitamin D status during pregnancy and risk of childhood asthma: A meta-analysis of prospective studies. Mol Nutr Food Res 2016. (epub ahead of print) https://doi.org/10.1002/mnfr.201600657

15. Mai X-M, Langhammer A, Camargo CA, Chen Y. Serum 25-hydroxyvitamin D levels and incident asthma in adults. The HUNT Study. Am J Epidemiol 2012;176(12):11691176. https://doi.org/10.1093/aje/kws235

16. Korn S, Hubner M, Jung M, Blettner M, Buhl R. Severe and uncontrolled adult asthma is associated with vitamin D insufficiency and deficiency. Respir Res 2013;14(1):25. https://doi.org/10.1186/1465-9921-14-25

17. Castro M, King TS, Susan J, Kunselman SJ, et al. Effect of vitamin D3 on asthma treatment failures in adults with symptomatic asthma and lower vitamin D levels. The VIDA randomized clinical trial. JAMA 2014;311(20):2083-2091. https://doi. org/10.1001/jama.2014.5052
18. Martineau AR, MacLaughlin BD, Hooper RL, et al. Double-blind randomized placebo-controlled trial of bolus-dose vitamin D3 supplementation in adults with asthma (ViDiAs). Thorax 2015;70(5):451-457. https://doi.org/10.1136/ thoraxjnl-2014-206260.101

19. Martineau AR, Cates CJ, Urashima M, et al. Vitamin D for the management of asthma. Cochrane Database Syst Rev 2016;2016(9):CD011511. https://doi. org/10.1002/14651858.CD011511.pub2

20. Janssens W, Bouillon R, Claes B, et al. Vitamin D deficiency is highly prevalent in COPD and correlates with variants in the vitamin D-binding gene. Thorax 2010;65(3):215-220. https://doi.org/10.1136/thx.2009.120659

21. Heulens N, Korf H, Janssens W. Innate immune modulation in chronic obstructive pulmonary disease: Moving closer toward vitamin D therapy. J Pharmacol Exp Ther 2015;353(2):360-368. https://doi.org/10.1124/jpet.115.223032

22. Kunisaki KM, Niewoehner DE, Connet JE. Vitamin D levels and risk of acute exacerbations of chronic obstructive pulmonary disease. Am J Respir Crit Care Med 2012;185(3):286-290. https://doi.org/10.1164/rccm.201109-1644oc

23. Quint JK, Donaldson GC, Wassef N, et al. 25-hydroxyvitamin D deficiency, exacerbation frequency and human rhinovirus exacerbations in chronic obstructive pulmonary disease. BMC Pulm Med 2012;12(1):28. https://doi.org/10.1186/14712466-12-28

24. Lehouck A, Mathieu C, Carremans C, et al. High doses of vitamin D to reduce exacerbations in chronic obstructive pulmonary disease: A randomized trial. Ann Intern Med 156(2):105-114. https://doi.org/10.7326/0003-4819-156-2-20120117000004

25. Martineau AR, James WY, Hooper RL, et al. Vitamin D supplementation in patients with chronic obstructive pulmonary disease ( $\mathrm{ViDiCO})$ : A multicentre, doubleblind, randomised controlled trial. Lancet Respir Med 2015;3(2):120-130. https:// doi.org/10.1016/s2213-2600(14)70255-3

26. Berk SM, Edgington BD, Rector TS, Kunisaki KM. Supplemental vitamin D and physical performance in COPD: A pilot randomized trial. Int J COPD 2013;8:97-104. https://doi.org/10.2147/copd.s40885

27. Holmgaard DB, Mygind LH, Titlestad IL, et al. Serum vitamin D in patients with chronic obstructive pulmonary disease does not correlate with mortality - results from a 10-year prospective cohort study. PLOS ONE 2013;8(1):e53670. https://doi. org/10.1371/journal.pone.0053670

28. Liu PT, Stenger S, Li H, et al. Toll-like receptor triggering of a vitamin D-mediated human antimicrobial response. Science 2006;311(5768):1770-1773. https://doi.org/ $10.1126 /$ science. 1123933

29. Powe CE, Evans MK, Wenger J, et al. Vitamin D-binding protein and Vitamin D status of black Americans and white Americans. N Engl J Med 2013;369(21):1991-2000. https://doi.org/10.1056/nejmoal306357

30. Holick MF. Bioavailability of vitamin D and its metabolites in black and white adults N Engl J Med 2013;369(21):2047-2048. https://doi.org/10.1056/nejme1312291

31. Wilkinson RJ, Llewelyn M, Toossi Z, et al. Influence of vitamin D deficiency and vitamin D receptor polymorphisms on tuberculosis among Gujarati Asians in west London: A case control study. Lancet 2000;355(9204):618-621. https://doi. org/10.1016/s0140-6736(99)02301-6

32. Martineau AR, Nhamoyebonde S, Oni T, et al. Reciprocal seasonal variation in vitamin D status and tuberculosis notifications in Cape Town, South Africa. Proc Nat Acad Sci USA 2011;108(47):19013-19017. https://doi.org/10.1073/pnas.1111825108

33. Realegeno S, Modlin RL. Shedding light on the vitamin D-tuberculosis-HIV connection. Proc Natl Acad Sci USA 2011;108(47):18861-18862. https://doi. org/10.1073/pnas.1116513108

34. Salahuddin N, Ali F, Hasan Z, et al. Vitamin D accelerates clinical recovery from tuberculosis: Results of the SUCCINT study (Supplementary Cholecalciferol in Recovery from Tuberculosis). A randomized, placebo-controlled, clinical trial of vitamin D supplementation in patients with pulmonary tuberculosis. BMC Infect Dis 2013;13(1):22. https://doi.org/10.1186/1471-2334-13-22

35. Coussens AK, Wilkinson RJ, Hanifa Y, et al. Vitamin D accelerates resolution of inflammatory responses during tuberculosis treatment. Proc Natl Acad Sci USA 2012;109(38):15449-15454. https://doi.org/10.1073/pnas.1200072109

36. Gunville CF, Mourani PM, Ginde AA. The role of vitamin D in prevention and treatment of infection. Inflamm Allergy Drug Targets 2013;12(4):239-245. https:// doi.org/10.2174/18715281113129990046

37. Youssef DA, Miller CWT, El-Abbassi AM, et al. Antimicrobial implications of vitamin D. Dermato-Endocrinol 2011;3(4):220-229. https://doi.org/10.4161/derm.3.4.15027

38. Muhe L, Lulseged S, Mason KE, Simoes EA. Case-control study of the role of nutritional rickets in the risk of developing pneumonia in Ethiopian children. Lancet 1997;349(9068):1801-1804. https://doi.org/10.1016/s0140-6736(96)12098-5 
39. Leow L, Simpson T, Cursons R, Karalus N, Hancox RJ. Vitamin D, innate immunity and outcomes in community acquired pneumonia. Respirology 2011;16(4):611-616 https://doi.org/10.1111/j.1440-1843.2011.01924.x

40. Remmelts HH, van der Garde EM, Meijvis SC, et al. Addition of vitamin D status to prognostic score improves the prediction of outcomes in community-acquired pneumonia. Clin Infect Dis 2012;55(11):1488-1494. https://doi.org/10.1093/cid/ cis751

41. Manaseki-Holland S, Qader G, Masher MI, et al. Effects of vitamin D supplementation to children diagnosed with pneumonia in Kabul: A randomised controlled trial. Trop Med Int Health 2010;15(10):1148-1155. https://doi.org/10.1111/j.13653156.2010.02578.x

42. Manaseki-Holland S, Maroof Z, Bruce J, et al. Effects on the incidence of pneumonia of vitamin D supplementation by quarterly bolus dose to infants in Kabul: A randomised controlled superiority trial. Lancet 2012;379(9824):1419-1427. https:// doi.org/10.1016/s0140-6736(11)61650-4

43. Choudary N, Gupta P. Vitamin D supplementation for severe pneumonia - a randomized controlled trial. Indian Pediatr 2012;49(6):449-454. https://doi. org/10.1007/s13312-012-0073-x

44. Zdrenghea MT, Makrinioti H, Bagacean C, et al. Vitamin D modulation of innate immune responses to respiratory viral infections. Rev Med Virol 2017;27(1):e1909. https://doi.org/10.1002/rmv.1909
45. Ginde AA, Blatchford P, Breese K, et al. High-dose monthly vitamin D for prevention of acute respiratory infection in older long-term care residents: A randomized clinical trial. J Am Geriatr Soc 2016. (epub ahead of print) https://doi.org/10.1111/jgs.14679

46. Bergman P, Norlin AC, Hansen S, et al. Vitamin D3 supplementation in patients with frequent respiratory tract infections: A randomised and double-blind intervention study. BMJ Open 2012;13;2(6):e001663. https://doi.org/10.1136/ bmjopen-2012-001663

47. Martineau AR, Jolliffe DA, Hooper RL, et al. Vitamin D supplementation to prevent acute respiratory tract infections: Systematic review and meta-analysis of individual participant data. BMJ 2017;356(6583). (epub ahead of print) https://doi.org/10.1136/ bmj.i6583

48. Simoneau T, Bazzaz O, Sawicki GS, Gordan C. Vitamin D status in children with cystic fibrosis. Ann Am Thorac Soc 2014;11(2):205-210. https://doi.org/10.1513/ annalsats.201306-171bc

49. McCauley LA, Thomas W, Laguna TA, et al. Vitamin D deficiency is associated with pulmonary exacerbations in children with cystic fibrosis. Ann Am Thorac Soc 2014;11(2):198-204. https://doi.org/10.1513/annalsats.201208-068oc

50. Pincikova T, Paquin-Proulx D, Sandberg JK, Flodström-Tullberg M, Hjelte L. Clinical impact of vitamin D treatment in cystic fibrosis: A pilot randomized, controlled trial. Eur J Clin Nutr 2017;71(2):203-205. https://doi.org/10.1038/ejcn.2016.259

51. Plum LA, DeLuca HF. Vitamin D, disease and therapeutic opportunities. Nat Rev Drug Discov 2010;9(12):941-955. https://doi.org/10.1038/nrd3318 